\title{
KURIKULUM KEPRIBADIAN SANTRI DI INDONESIA
}

\author{
Zulkifli \\ zulkifli.abudaud@gmail.com \\ (Fakultas Agama Islam Universitas Muhammadiyah Tangerang)
}

\begin{abstract}
Abstrak:
Kurikulum merupakan suatu rencana yang tersusun untuk kelancarkan proses belajar mengajar di bawah bimbingan dan tanggung jawab sekolah atau lembaga pendidikan beserta staf pengajaran. Kurikulum memiliki posisi strategis karena secara umum kurikulum merupakan deskripsi dari visi, misi, dan tujuan pendidikan sebuah bangsa. Adapun tujuan dari penelitian ini adalah: 1)Untuk menganalis tujuan perencanaan kurikulum kepribadian santri; 2)Untuk menganalisis program kurikulum kepribadian santri; 3)Untuk menganalisis implementasi perencanaan kurikulum kepribadian santri; 4)Untuk menganalisis sistem evaluasi kurikulum kepribadian santri; 5) Untuk menganalisis faktor pendukung dan faktor penghambat dari kurikulum kepribadian santri; 6) Untuk menganalisis tingkat keberhasilan kurikulum kepribadian santri. Kurikulum yang baik ditandai dengan jelasnya tujuan, program, terlaksananya proses dengan baik, evaluasi yang dapat diukur, serta mampu memetakan faktor penghambat dan pendukung.
\end{abstract}

\section{Kata Kunci : Kurikulum, Kepribadian, Santri.}

Abstract:
The curriculum is a plan that is structured for the smooth running of the teaching and learning process under the guidance and responsibility of schools or educational institutions and teaching staff. The curriculum has a strategic position because in general it is a description of the vision, mission and educational goals of a nation. The objectives of this study are: 1) To analyze the objectives of the student personality curriculum planning; 2) To analyze the student personality curriculum program; 3) To analyze the implementation of the student personality curriculum planning; 4) To analyze the student personality curriculum evaluation system; 5) To analyze the supporting and inhibiting factors of the student personality curriculum; 6) To analyze the success rate of the student personality curriculum. A good curriculum is marked by clear objectives, programs, well-executed processes, measurable evaluation, and being able to map inhibiting and supporting factors.

\section{Keywords: Curriculum, Personality, Santri}

\section{A. Pendahuluan}

Pendidikan adalah salah satu wadah atau tempat berisi suatu proses belajar mengajar yang diartikan sebagai suatu rangkaian interaksi antara peserta didik dan guru dalam mencapai tujuan ${ }^{1}$. Pendidikan

${ }^{1}$ Tri Rizqi Ariantoro, Dampak Game Online Terhadap Prestasi Belajar Pelajar, Jutim, Vol 1, No. 1, Desember (2016) juga diartikan sebagai suatu proses pertumbuhan individu yang berlangsung sepanjang masa. Berkaitan dalam konsep pendidikan seumur hidup yang sangat penting dan tidak dapat dipisahkan dengan interaksi manusia. Sehingga, konsekuensinya harus dilaksanakan dengan sebaik-baiknya untuk memperoleh hasil yang diharapkan. Pendidikan adalah alat 
atau sarana bagi setiap manusia untuk mengembangkan keilmuan dan pengetahuan, oleh karena itu pendidikan diharapkan memiliki konsep pendidikan dan dasar-dasar yang tertata, dan memiliki etika.

Aktivitas pendidikan baik dalam penyusunan konsep teoritis maupun dalam pelaksanaan operasionalnya harus memiliki dasar yang kokoh dengan berpedoman kepada etika akademis ${ }^{2}$. Dewasa ini, tantangan pendidikan dalam hal ini adalah yang dihadapi oleh para peserta didik di dalam dan diseluruh dunia pendidikan termasuk di dalam lingkungan pesantren tengah menghadapi tantangan serius. ${ }^{3}$ Salah satu komponen penting pada lembaga pendidikan formal yang digunakan sebagai acuan untuk menentukan isi pengajaran, mengarahkan proses mekanisme pendidikan, tolok-ukur

${ }^{2}$ Mursal Aziz, Etika Akademis Dalam Pendidikan Islam, Jurnal Tarbiyah, Vol. 25, No. 1, Januari-Juli (2018).

${ }^{3}$ QS. Al-Qashash ayat 77: "Dan carilah apa yang telah dianugerahkan Allah kepadamu (kebahagiaan ) negeri akhirat, dan janganlah kamu melupakan kebahagiannmu dari (kenikmatan) duniawi dan berbuat baiklah kepada orang lain sebagaimana Allah telah berbuat baik kepadamu". Soenarjo, Al-Qur'an dan Terjemahnya ( Jakarta: Depag RI, 2015), 623. Secara implisit, ayat ini menekankan kepada proses pendidikan yang menitikberatkan kepada dua persoalan yang sangat penting secara berimbang, yakni pembinaan, pengajaran, pelatihan dalam aspek jasmani dan pembinaan dan pembangunan ruhiyah atau jiwa. Bagi Islam, dua aspek penting ini merupakan sebuah kesatuan yang harus diusung secara bersama-sama untuk menumbuhkan dan mengembangkan potensi manusia dalam mencapai kesehjateraan material dan non-material. Kesehjateraan material harus menjadi pengantar kesehjateraan abadi yakni kehidupan di alam baka. Tidaklah Qur'ani bila pendidikan hanya berorientasi atau mengaksentuasikan usahanya pada menumbuh kembangkan aspek jasmani, sementara aspek rohani ditinggalkan. Ahmad Tafsir, Filsafat Pendidikan Islami, (Bandung: Rosdakarya, 2006), cet. Ke-1, 33 keberhasilan dan kualitas hasil pendidikan, adalah kurikulum. ${ }^{4}$ Kurikulum adalah program pendidikan yang disediakan oleh lembaga pendidikan bagi peserta didik. Berdasarkan program lembaga pendidikan tersebut siswa melakukan berbagai kegiatan belajar, sehingga mendorong perkembangan dan pertumbuhannya sesuai dengan tujuan pendidikan yang telah ditetapkan.

Pendidikan nasional berfungsi mengembangkan kemampuan dan membentuk watak serta peradaban bangsa yang bermartabat dalam rangka mencerdaskan kehidupan bangsa, bertujuan untuk berkembangnya potensi peserta didik agar menjadi manusia yang beriman dan bertaqwa kepada Tuhan Yang Maha Esa, berkahlaq mulia, sehat, berilmu, cakap, kreatif, mandiri dan menjadi warga negara yang demokratis serta bertanggung jawab. ${ }^{5}$ Secara tidak langsung semakin maju peradaban suatu masyarakat akan semakin bertambah banyak masalah yang harus dihadapi, termasuk dalam bidang pendidikan. Permasalahan pendidikan adalah amat banyak, antara satu masalah dengan masalah yang lain mempunyai hubungan yang kompleks di Indonesia dibandingkan dengan permasalahan pendidikan. Kompleksitas permasalahan pendidikan itu muncul tidak saja karena tuntutan perubahan internal dalam skala nasional bahkan skala lokal. ${ }^{6}$ Permasalahan tersebut menjadi tanggung jawab pendidikan terlihat kondisi sekolah sekarang ini nampaknya sudah teralinasi dengan semakin banyak siswa yang disibukkan dengan media sosial yang hadir sebagai dampak dari globalisasi. Salah satu

\footnotetext{
${ }^{4}$ S. Nasution, Kurikulum dan Pengajaran (Jakarta: Bumi Aksara, 1995), 50

${ }^{5}$ Lukmanul Hakim, Perencanaan Pembelajaran, (Bandung: CV. Wacana Prima, 2009), 92

${ }^{6}$ Ali Rohmat, Kapita Selekta Pendidikan, (Yogyakarta, Penerbit Teras, 2004), 3-4
} 
dampak dari penggunaan full time mereka terhadap gadjet yang seluruh aplikasinya berisi sosial media dan browser dengan adanya generasi yang lebih suka mencari jawaban dari internet dari pada berdiskusi untuk memecahkan sebuah permasalahan. Jika hal tersebut berlanjut tanpa adanya filter yang kuat dari pendidikan maka akibat yang ditimbulkan hanyalah dampak negatif. Dengan istilah lain ialah lahirnya handphone yang smart dan manusia yang bodoh atau idiot. Semua bentuk permasalahan pendidikan yang ada seolah membuat akademisi menjadi geram dan mulai mencari cara agar pendidikan Indonesia bangkit dan membawa Indonesia pada pemecahan masalah pendidikan yang continues dan berharap hingga sampailah negara Indonesia pada fase dimana Indonesia membuat kebijakan untuk mengganti kurikulum, memberi subsidi besar-besaran dalam pendidikan atau bahkan meningkakan kesejahteraan guru sebagai pemangku utama pendidikan. Meskipun telah berkali-kali Indonesia mencari konsep pendidikan melalui merubah kurikulum dan menetapkan berbagai kebijakan. Akan tetapi akan menjadi sia-sia ketika guru sebagai penopang utama pendidikan tetap menggunakan pola lama dalam pembelajarannya. Bahwa konsep pendidikan di Indonesia hanya akan menghasilkan output yang cerdas secara akademik dan kognitif tetapi nihil di afektif dan psikomotorik.

Cara yang seperti ini dijelaskan oleh Paulo Freire bahwa dalam hal ini pendidikan masih mengikuti sistem "gaya bank", yakni guru mengajar murid diajar, guru mengetahui segala sesuatu murid tidak tahu apa-apa, guru berpikir murid dipikirkan, guru bercerita murid patuh mendengarkan, guru menentukan peraturan murid diatur, guru memilih dan memaksakan pilihannya murid menyetujuinya, guru adalah subjek dalam belajar dan murid adalah objek belaka. ${ }^{7}$ Dalam konsep pendidikan lama situasi pembelajaran didominasi oleh guru. Peserta didik lebih bersifat pasif menerima sepenuhnya materi apa saja yang disampaikan dan diberikan guru. Kurikulum, mutlak direncanakan, disusun dan dibuat oleh pemerintah dan guru atau sekolah tanpa mengikutsertakan peserta didik. Terkait dengan hal tersebut berdasarkan studi psikologi dan sosiologi pendidikan, masyarakat pendidikan umumnya menghendaki perubahan dan hendaknya konsep pendidikan terutama dalam pengajaran agar lebih memperhatikan minat, kebutuhan dan kesiapan siswa untuk belajar. ${ }^{8}$

Berdasarkan tujuan tersebut Pemerintah Indonesia memiliki tanggung jawab mewujudkan masyarakat Indonesia menjadi masyarakat yang berkualitas. Pendidikan nasional bukan hanya sebatas peningkatan kualitas kehidupan namun pendidikan juga meningkatkan harkat dan martabat seseorang, maka seharusnya pendidikan dimulai dari sedini mungkin dalam mencetak generasi yang sholeh dan sholeha, jangan sampai menyengsarakan dan menelantarkan anak. Sebagaimana Allah mengingatkan manusia dalam firmannya surah An-Nisa surat 04 :9. ${ }^{9}$

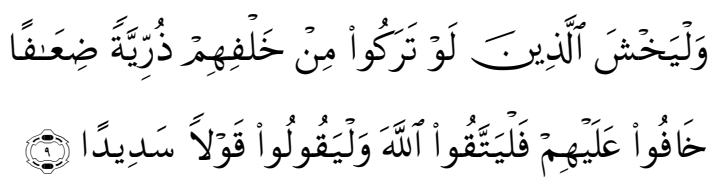

Dan hendaklah takut kepada Allah orangorang yang seandainya meninggalkan dibelakang mereka anak-anak yang lemah, yang mereka khawatir terhadap (kesejahteraan) mereka. oleh sebab itu hendaklah mereka bertakwa kepada Allah

\footnotetext{
${ }^{7}$ Paulo Freire, Pendidikan Kaum Tertindas, (Jakarta: LP3S, 1985), 51-52

8 Wasti Soemanto, Psikologi Pendidikan, (Jakarta: Rineka Cipta, 2006), 205

9 Al-Qur'an Al-Karim, Departemen Agama
} 
dan hendaklah mereka mengucapkan perkataan yang benar.

Perkembangan zaman yang terus berkembang dapat merubah keadaan sosial, ekonomi, budaya bahkan pola fikir masyarakat, maka atas dasar itulah pengembangan kurikulum merupakan keniscayaan bagi institusi pendidikan agar proses dan hasil pendidikan tidak menyimpang dengan harapan mampu menjawab kebutuhan masyarakat sesuai tuntutan zaman. Permasalahan dan pengembangan serta kehidupan manusia terus berkembang pesat ketika bersentuhan dengan ilmu pengetahuan dan teknologi. Dalam hal ini para pakar pendidikan berusaha meramu sebuah kurikulum yang tepat, karena salah satu komponen pendidikan yang menjadi tolak ukur dan ruhnya adalah kurikulum dalam keberhasilan pendidikan di sebuah negara. ${ }^{10}$ Dalam proses pengembangan kurikulum, banyak sekali masalahyang dihadapi, yang memerlukan pertimbangan dan pemecahan tersendiri. Semua masalah tersebut disebabkan oleh berbagai kondisi yang ada, yang disesuaikan dengan tuntutan dan prinsip kebutuhan yang perlu dipahami. Berbagai masalah yang termasuk dalam masalah umum dapat dikelompokkan menjadi delapan kelompok, yaitu bidang cakupan (skope), relevansi, keseimbangan, integrasi, sekuens, kontinuitas, artikulasi, dan kemampuan transfer (transfer ability) ${ }^{11}$.

Pengembangan kurikulum harus dilandasi oleh manajemen berdasarkan pertimbangan-pertimbangan multidimensional, sebagai berikut.

1. Manajemen sebagai suatu disiplin ilmu sangat erat kaitannya dengan disiplin

\footnotetext{
${ }^{10}$ Zaenal Arifin, Pengembangan Manajemen Mutu Kurikulum Pendidikan Islam (Bandung: PT.Remaja Rosdakarya, 2012), 84

${ }^{11}$ Oemar Hamalik, Manajemen Pengembangan Kurikulum, (Bandung: Rosdakarya, 2006), 5
}

ilmu-ilmu lainnya, seperti filsafat, psikologi, sosial budaya, sosial teknologi.

2. Para pengembang kurikulum mengikuti pola pikir yang sinkron dengan pola dan struktur berfikir dalam manajemen.

3. Implementasi kurikulum sebagai bagian integral dalam pengembangan kurikulum membutuhkan konsepkonsep, prinsip-prinsip, dan prosedur serta pendekatan manajemen.

4. Pengembangan kurikulum tidak lepas dari kebijakan di bidang pendidikan, yang bersumber dari kebijakan pendidikan nasional.

5. Kebutuhan manajemen di sektor bisnis dan industri.

Dewasa ini pesantren dihadapkan pada banyak tantangan termasuk di dalamnya modernisasi pendidikan Islam. Dalam banyak hal, sistem dan kelembagaan pesantren telah dimodernisasi dan disesuaikan dengan tuntutan pembangunan, terutama dalam aspek kelembagaan yang secara otomatis akan mempengaruhi penetapan kurikulum yang mengacu pada tujuan institusional lembaga tersebut. Selanjutnya, persoalan yang muncul adalah apakah pesantren dalam menentukan kurikulum harus melebur pada tuntutan jaman sekarang, atau justru ia harus mampu mempertahankannya sebagai ciri khas pesantren yang banyak hal justru lebih mampu mengaktualisasikan eksistensinya di tengah-tengah tuntutan masyarakat. Pondok pesantren adalah pendidikan Islam tradisional pertama di Indonesia. Pesantren merupakan sebuah institusi pendidikan Islam, bertujuan untuk mempelajari, menghayati, dan mengamalkan ajaran Islam dengan menekankan pentingnya aspek moral 
keagamaan sebagai pedoman perilaku hidup sehari-hari. ${ }^{12}$

Upaya untuk memaksimalkan proporsi pengetahuan agama dan umum di pesantren memunculkan upaya perpaduan aspek-aspek kurikulum dalam sebuah integritas kurikulum. Adapun pola adaptasi ini sebagai respon sebuah perubahan yang dapat menjadi transformasi perkembangan zaman dalam membentuk kepribadian dan karakter sebuah bangsa. ${ }^{13}$ Maka sebuah keniscayaan bahwa perkembangan paradigma pendidikan pesantren Pesantren adalah bentuk pendidikan tradisional di Indonesia yang sejarahnya telah mengakar secara berabad-abad. Nurcholis Madjid menyebutkan, bahwa pesantren mengandung makna ke Islaman sekaligus keaslian (indigenous) Indonesia. ${ }^{14}$ Pondok pesantren adalah suatu lembaga pendidikan agama Islam yang tumbuh serta diakui oleh masyarakat sekitar, dengan sistem asrama (kampus) yang santri-santrinya menerima pendidikan agama melalui sistem pengajian atau madrasah yang sepenuhnya berada di bawah kedaulatan dan kepemimpinan seorang atau beberapa orang kyai dengan ciri-ciri khas yang bersifat kharismatis serta independen dalam segala hal. ${ }^{15}$ Dalam mencetak karakter anak bangsa para ustadz dan kyai mengkedepankan akhlak sebagai pondasi kehidupan. Sebagaimana firman Allah SWT surah Al-Qolam ayat 4.

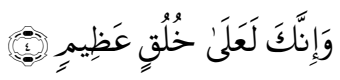

${ }^{12}$ A. Rofiq, dkk. Pemberdayaan Pesantren. (Yogyakarta: LKIS, 2005), 1.

${ }^{13}$ Yunus Abu Bakar, Konsep Pemikiran Imam Zarkasi, (Ponorogo: Darussalam Press, 2014), 52

${ }^{14}$ Nurcholis Madjid, Bilik-Bilik Pesantren (Jakarta:Paramadina, 2006), 107.

${ }^{15}$ Djamaluddin \& Abdullah Aly, Kapita Selekta Pendidikan Islam (Bandung: Pustaka Setia, 2000), 99.
Dan Sesungguhnya kamu benar-benar berbudi pekerti yang agung.

Al-Hasan Al-Bashri berkata, "Ia ( "khuluq" dalam Ayat ini) adalah adabadab Al-Qur'an".'Aisyah radhiallahu 'anha pernah ditanya tentang akhlak Rasulullah shallallahu 'alaihi wa sallam, maka beliau pun menjawab, "Akhlak beliau adalah (melaksanakan seluruh yang ada dalam) Al-Qur'an". Qatadah mengatakan, Ia ("Khuluq" dalam Ayat ini) adalah sesuatu yang beliau laksanakan dari perintah Allah dan sesuatu yang beliau jauhi dari larangan Allah, dan makna Ayat di atas: Sesungguhnya engkau benar-benar berakhlak dengan akhlak yang diperintahkan Allah dalam Al-Qur'an. ${ }^{16}$ Dalam hal ini pondok pesantren bukan hanya imu dunia yang diajarkan tetapi yang lebih penting pengamalan dimasyarakat yang akan terlihat, keluaran setelah menimba ilmu dipesantren dibina dan dibiasakan dalam hal-hal yang baik.

Berkenaan dengan pentingnya pengembangan kurikulum yang harus tersusun atas dasar sumber pengetahuan yang benar sesuai dengan Al-Qur'an dan Hadits sehingga para santri memiliki pandangan hidup dan keahlian yang memadai sebagai bekal ketika mereka selesai pengabdian dari pondok. ${ }^{17}$ Lembaga pendidikan yang disebut pondok pesantren sebagai pusat penyiaran Islam tertua yang lahir dan berkembang seirama dengan masuknya Islam di Indonesia. Pada awalnya berdirinya, pondok pesantren umumnya sangat sederhana. Kegiatan pembelajaran biasanya diselenggarakan di langgar (mushala) atau masjid oleh seorang kyai dengan beberapa orang santri yang datang mengaji. Lama kelamaan

${ }^{16}$ https://muslim.or.id/24784-keutamaanrasulullah-shallallahualaihi-wasallam-dalam-alquran-2.html

${ }^{17}$ Hasil wawancara dengan Ustadaz Kusnadi, (Pengurus Yayasan Pondok Pesantren Al-Amanah Al Gontory), pada tanggal 22 juli 2017 
"pengajian" ini berkembang seiring dengan pertambahan jumlah santri dan pelebaran tempat belajar sampai menjadi sebuah lembaga yang unik, yang disebut pesantren. ${ }^{18}$

Serta adanya bermacam-macam tujuan dan latar belakang dibalik adanya sorotan tersebut, ada yang positif, yaitu dengan tujuan mencari alternatif sistem pendidikan yang ada di pesantren sudah dinilai tidak sesuai dengan tuntutan zaman bahkan dirasa tidak benar, sehingga pesantren merasa terangsang dan merenovasi untuk berbenah diri dengan mencari dan merubah sistem yang dianggap perlu diganti. Lebih lanjut Menteri Agama Republik Indonesia mengatakan bahwa : Pesantren memiliki fungsi sebagai berikut :

a. Sebagai lembaga pendidikan yang meletakkan transfer ilmu-ilmu agama (tafaqquh fidin) dan nilai-nilai Islam (Islamic Values).

b. Sebagai lembaga keagamaan yang melakukan kontrol social (Social Control).

c. Sebagai lembaga keagamaan yang melakukan rekayasa social (Social Engineering). ${ }^{19}$

\section{B. Landasan Teori}

1. Grand Theory: Teori Konversi Agama Glock \& Stark. Glock dan Stark mendefinisikan agama sebagai sistem simbol, sistem keyakinan, sistem nilai, dan sistem perilaku yang membentuk kepribadian dan terlembaga, yang kesemuanya terpusat pada persoalanpersoalan yang dihayati sebagai yang paling maknawi. ${ }^{20}$ Glock \& Stark

${ }^{18}$ Husni Rahim , Arah Baru Pendidikan Islam di Indonesia (Jakarta: Logos, 2001), 157.

${ }^{19}$ Djamaluddin \& Abdullah Aly, Kapita Selekta Pendidikan Islam (Bandung: Pustaka Setia, 2000), 99.

${ }^{20}$ Zakiah Daradjat, Ilmu Jiwa Agama, (Jakarta: Bulan Bintang, 2005), 10. mengatakan bahwa komitmen beragama terbagi atas beberapa dimensi, yaitu dimensi keyakinan, dimensi ritual, dimensi penghayatan, dimensi intelektual dan dimensi konsekuensial. Skema ini dibuat oleh Glock untuk menampakkan perbedaan antara apa yang orang meyakini dalam kebenaran agamanya, apa yang mereka lakukan dalam bagian praktik dari yang mereka percayai, bagaimana emosi dan pengalaman secara sadar terlibat dalam agama mereka. Glock meringkas kedalam analisis konsisten dan pembiasaan dalam beragama dalam lima hal yaitu; keyakinan, ritual, penghayatan, pengetahuan dan pengaruh.

2. Middle Theory: Teori Belajar Carl Rogers, Jean Piaget, Vygotsky, E.L Thorndike dan Skinner Teori pertama adalah teori pembelajaran humanistik yaitu teori belajar yang memanusiakan manusia. Pembelajaran dipusatkan pada pribadi seseorang. Teori ini tidak lepas dari pendidikan yang berfokus pada bagaimana menghasilkan sesuatu yang efektif, bagaimana belajar yang bisa meningkatkan kreativitas dan memanfaatkan potensi yang ada pada seseorang. Jean Piaget dalam teorinya memaknai dengan aktivitas yang aktif peserta didik dapat menambah ilmu pengetahuannya dengan cara mengeksplorasi dari apa yang dipelajari yang merupakan proses konsep dan ideide mengarah kepada kerangka berfikir yang sudah ada. Dalam hal ini proses menemukan teori yang dibangun dari objek lapangan. Vygotsky dalam teorinya memiliki ide utama yaitu; mengembangkan intelektual yang didasarkan pada pengalaman, pengembangan kognitif anak dengan cara berkomunikasi. Teori kedua tentang pembelajaran yang digagas oleh E.L Thorndike dan Skinner yang 
mengatakan bahwasannya pembelajaran yang menyambungkan serta memberikan stimulus dan respon. Dengan adanya keteguhan dan konsisten serta fokus dalam berkomunikasi dapat memperkuat dan mendorong dalam proses belajar. ${ }^{21}$

3. Applied Theory: Teori Kepribadian William Stern (1871-1938) dan Adler William Stern dan Adler berpendapat tentang aliran Konvergensi adalah aliran yang menggabungkan dua aliran di atas. Konvergensi adalah interaksi antara faktor hereditas dan faktor lingkungan dalam proses pemunculan tingkah laku. Menurut aliran ini, hereditas tidak akan berkembang secara wajar apabila tidak diberi rangsangan dari faktor lingkungan. Sebaliknya, rangsangan lingkungan tidak akan membina kepribadian yang ideal tanpa didasari oleh faktor hereditas. Penetuan kepribadian seseorang ditentukan kerja yang integral antara internal (potensi bawaan) maupun faktor eksternal (lingkungan pendidikan). Kepribadian manusia ditentukan oleh faktor dasar dan pengajaran. ${ }^{22}$ Abdullah Nashih 'Ulwan berpendapat faktor yang menjadikan kepribadian pada anak dengan memaksimalkan keteladanan, pembiasaan, nasehat dan penghargaan dalam hal ini dilakukan secara maksimal. ${ }^{23}$ Adapun hasil dari pengamatan kurikulum kepribadian ini adalah sebagai berikut:

\section{a. Tujuan Perencanaan kurikulum}

\footnotetext{
${ }^{21}$ Muhammad Thobroni dan Arif Mustofa, Belajar dan Pembelajaran Pengembangan Wacana dan Praktik Pembelajaran dalam Pembangunan Nasional, (Jogyakarta: Ar-Ruzz Media, 2011), 77.

${ }^{22}$ Hartati, N. , dkk, Islam dan Psikologi, (Jakarta: PT.Raja Gravindo Persada), 163-164.

${ }^{23}$ Abdullah Nashih Ulwan, Pedoman Pendidikan Islam, terj. Saifullah Kamlie dan Hery Noer Ali, (Semarang: CV Asy Syifa, 1993), Jilid 2, $1-2$.
}

kepribadian santri. Pertama meningkatkan mutu kurikulum pembelajaran, Peningkatan mutu kualitas dalam kurikulum pembelajaran adalah suatu perencanaan yang harus dikerjakan oleh semua warga ponpes yang terdiri dari pendidik yaitu ustadz dan santri untuk memperbaiki kualitas kurikulum mutu dalam pembelajaran secara terus menerus sehingga tujuan pembuatan kurikulum pembelajaran dapat berjalan secara efektif dan efisien, guna memberi tambah pada hasil lulusan dari suatu lembaga pendidikan dalam hal ini adalah ponpes. Kedua memiliki kepribadian muslim yang ideal, yaitu santri yang dapat dengan benar dalam melaksanakan aktivitas hidupnya seperti mendirikan shalat, menunaikan zakat, memberi sedekah, selalu menepati janji apabila ia berjanji, dan selalu berusaha untuk bersabar dalam kesempitan maka santri tersebut dikatakan bertakwa dan dinyatakan santri yang benar. Indikatornya muslim yang memiliki kepribadian ideal adalah: (1) santri yang berakhlak karimah adalah santri yang menyandarkan semua prilaku dalam kehidupan berdasarkan pada prilaku Rasulullah dan sahabat salafussholeh. (2) Kepribadian santri yang berakidah salimah, kepribadian santri yang totalitas hidupnya menyerahkan diri pada Allah SWT. (3) kesadaran bahwa santri adalah pengembang dakwah.

b. Program kurikulum kepribadian santri, Substansi kurikulum kepribadian santri meliputi:

1. Pembinaan atau pengajaran, meliputi: Mengajarkan dasardasar Aqidah Islamiyah melalui kegiatan rutinitas berupa kajian, dasar-dasar ilmu perbandingan agama, melakukan kegiatan pelatihan khutbah atau muhadhoroh dan kegiatan wirausaha kepada santri.

2. Membaca kitab-kitab klasik, memiliki sikap kreatifitas dalam 
berwirausaha, dan menghafal alQur'an.

3. Program pengembangan, terdiri dari: menghafal Al-Qur'an dan tafsirnya, menghafal hadits dan syarahnya, penguasaan bahasa Inggris dan komputer.

c. Proses Pelaksanaan Pembinaan Kurikulum Kepribadian Santri

Proses pelaksanaan kurikulum kepribadian dibagi menjadi tiga yaitu, pendidikan, pengajaran dan pembiasaan. Tahapan pertama, memberikan pemahaman tentang pendidikan aqidah Islamiyah, Tahapan kedua, mengajarkan dalam meyakini suatu perbuatan yang terdapat dalam nilai-nilai kebenaran yang menjadikan suatu acuan dalam kehidupan, Tahapan ketiga, membiasakan nilai-nilai kebenaran dalam kehidupan berupa akhlakul karimah.

d. Evaluasi Kurikulum Kepribadian Santri. Evaluasi yang dilakukan dengan dua proses yaitu, evaluasi dari hasil pendidikan formal dengan dokumen nilai raport dan kegiatan raport mental asrama atau kegiatan sehari-hari yang dilakukan oleh santri. Rincian tersebut meliputi: pertama, catatan hasil belajar yang dibuat oleh guru atau ustadz dalam pendidikan formal di kelas dengan dokumen khusus yang dipegang oleh asatidz, kedua, dokumen catatan akhlak dan prilaku santri yang dibuat dalam buku panduan harian beribadah.

e. Faktor-faktor pendukung dan penghambat kurikulum kepribadian santri. Setelah diidentifikasi melalui analisis SOAR, yaitu: pertama, Strength (kekuatan), antara lain: 1) Keberadaan pesantren telah memberi perubahan pada kehidupan keberagamaan bagi santri dan warga di sekitarnya; 2) Santri yang mengalami peningkatan dari tahun ke tahun; 3) Kerjasama dari berbagai pihak untuk merangkul dan memberikan pembinaan kepada para santri sesuai pengembangan kurikulum; 4) Terselenggaranya pendukung kegiatan pembelajaran, pembiasaan sesuai pembentukan kepribadian santri dan asatidz; 5) Tersedianya fasilitas yang memadai dalam penunjang kurikulum dan pembentukan kepribadian santri; 6) Adanya masjid sebagai sarana prasarana laboratorium santri dalam pembinaan kepribadian. Kedua, Opportunity (peluang) dalam sistem kelembagaan memiliki kesempatan mengembangkan kurikulum dan memiliki kesempatan berkembang dengan pesat ditandai dengan banyaknya santri yang melanjutkan ke perguruan tinggi luar negri dan banyaknya santri yang hafidz Qur'an bahkan tersalurkan bakat ke masjid-masjid dengan menjadi da'i. Ketiga, Asprations (langkah masa depan yang diinginkan), Pondok Pesantren berkembang dengan pesat dengan kurikulum perpaduan antara nasional serta departemen agama dan kurikulum pesantren, dengan dukungan pimpinan pondok untuk bisa menjadi ponpes maju ditingkat internasional. Keempat, Result (hasil), Result ini terlihat dari semakin banyak dan bertambahnya santri yang ingin belajar menimba ilmu agama dan menjadi tempat studi banding antar pondok dalam kurikulumnya.

f. Tingkat keberhasilan pelaksanaan kurikulum kepribadiaan santri Melalui pondok pesantren para santri mengalami perubahan prilaku tentang cara berkomunikasi, dan bergaul ketika selesai mondok ditengah masyarakat serta memiliki keahlian. Dari indikator keberhasilan kurikulum kepribadian santri didasarkan pada teori Glock dan Stark bahwa proses pelaksanaan kurikulum kepribadian santri di pondok pesantren pada santri cukup baik, efektif bahkan optimal dalam pembentukan kepribadian religiusitas Islam (akhlakul karimah) lewat kurikulumnya bagi santri. 


\section{Penutup}

Berdasarkan uraian dan analisa kurikulum kepribadian santri sebelumnya, maka dapat disimpulkan sebagai berikut:

1. Peningkatan mutu dalam kurikulum kepribadian santri di indonesi dalam hal ini pembelajaran yang bertujuan pertama; sebagai perencanaan yang dilakukan oleh semua warga pondok pesantren, dengan dalam menghasilkan kurikulum pembelajaran yang sangat efektif dan efisien. Kedua dapat memiliki kepribadian muslim yang ideal dalam hal ini santri memiliki akhlak karimah, santri memiliki aqidah salimah, santri adalah khalifah yang menjaga dan memelihara bumi Allah SWT.

2. Program kurikulum kepribadian santri meliputi. Pertama, pembinaan atau pengajaran mengenai aqidah Islamiyah. Kedua, membaca kitab-kitab klasik, Ketiga program pengembangan yaitu bakat dari santri tersebut dengan cara, ekskul Tahfidz Qur'an, bahasa Inggris dan kewirausahaan.

3. Proses pelaksanaan pembinaan kurikulum kepribadian dilakukan dengan beberapa tahapan yaitu; Pertama, memberikan pemehaman tentang pendidikan Islam. Kedua, mengajarkan nilai-nilai kebenaran dalam kehidupan. Ketiga, pembiasaan nilai-nilai kebenaran dalam kehidupan sehari-hari.

4. Evaluasi pada pondok pesantren dilakukan dengan dua proses yaitu Pertama, mengevaluasi dari hasil pendidikan formal berupa dokumen raport. Kedua, dengan adanya raport mentalatau kegiatan sehari-hari yang dilakukan di asrama.

5. Faktor penghambat dan pendukung didasarkan pada analisis SOAR, yaitu Strenght, keberadaan Pondok pesantren telah memberi perubahan pada kehidupan keberagamaan. Opportunity, sistem kelembagaan memiliki kesempatan berkembang pesat dengan kurikulum kepribadian santri Internasional dipondok pesantren. Aspiration, keinginan menjadi ponpes Internasional menjadi kenyataan. Result, semakin banyak dan bertambah ponpes yang ingin menimba ilmu di pondok pesantren. Keenam, keberhasilan kurikulum kepribadian santri cukup baik dan efektif dalam membentuk pribadi yang religius dan berkarakter Islami.

6. Tingkat keberhasilan pelaksanaan kurikulum kepribadian santri di pondok pesantren dengan melihat indikator setelah santri selesai mondok antara lain. Pertama, memiliki keahlian menjadi imam masjid. Kedua, menjadi guru atau dosen setelah melanjutkan jenjang pendidikannya. Ketiga, menjadi pengusaha karena selama menjadi santri dibekali ilmu kewirausahaan.

7. Profil pondok-pondok pesantren telah memenuhi syarat dalam membentuk kepribadian Islami dengan adanya kurikululum berbasis Al-Qur'an, antara lain dengan adanya Visi dan Misi yang ada di dalam kurikulum kepribadian santri dalam terwujudnya Insan yang Berakhlakul Karimah, Cerdas dalam Intelegensi, Emosi, Spiritual dan berguna untuk kehidupan di masa depan.

\section{DAFTAR PUSTAKA}

Al-Qur'an Al-Karim, Departemen Agama Abdullah Nashih 'Ulwan, Pendidikan Anak dalam Islam, Jakarta: Pustaka Amani

Ali Rohmat, Kapita Selekta Pendidikan, Yogyakarta, Teras, 2004, 3-4

Ahmad Zaini, Dunia Pemikiran Kaum Santri, Yogyakarta: LKPSM NU DIY, 1995 
Ahmad Tafsir. 1992. Ilmu Pendidikan Dalam Perspektif Pendidikan Islam.

Ahmad, M. dkk. 1998. Pengembangan Kurikulum. Bandung: Pustaka Setia.

Dadang Kahmad. 2009. Metode Penelitian Agama (Perspektif Ilmu Perbandingan Agama), Bandung: Pustaka Setia. dan Aplikasi. Jakarta: Grasindo. dan Instrumen. Bandung: Refika Aditama. dan Kerangka Dasar Operasinalisasinya. Bandung: Trigenda Karya.

Djamaluddin \& Abdullah Aly, Kapita Selekta Pendidikan Islam (Bandung: Pustaka Setia, 2000), 99.

Hartati, N. , dkk, Islam dan Psikologi, (Jakarta: PT.Raja Gravindo Persada), 163-164.

Hamalik, Oemar. 2006. Manajemen Pengembangan Kurikulum. Bandung

Hasil wawancara dengan Kepala Sekolah Madrasah Tsanawiyah Al-Amanah Al-Gontory Ust.Muhammad Kusnadi.

Husni Rahim , Arah Baru Pendidikan Islam di Indonesia (Jakarta: Logos, 2001), 157

Lukmanul Hakim, Perencanaan Pembelajaran, Bandung, CV.Wacana Prima, 2009, 92
Mursal Aziz, Etika Akademis Dalam, Pendidikan Islam, Jurnal Tarbiyah, Vol.25, No. 1, Januari-Juli 2018

Muhammad Thobroni dan Arif Mustofa, Belajar dan Pembelajaran Pengembangan Wacana dan Praktik Pembelajaran dalam Pembangunan Nasional, (Jogyakarta: Ar-Ruzz Media, 2011), 77

Nurcholis Madjid, Bilik-Bilik Pesantren (Jakarta:Paramadina, 2006), 107

Oemar Hamalik. 2006. Pendidikan Guru Berdasarkan Pendekatan Kompetensi, Jakarta: Bumi Aksara.

S. Nasution. Asas-Asas Kurikulum, Jakarta: PT. Bumi Aksara

Tohirin, Psikologi Pembelajaran Pendidikan Agama Islam (Jakarta: PT Raja Grafindo Persada, 2005).

Umiarso dan Imam Gojali. 2010. Manajemen Mutu Sekolah di Era Otonomi Pendidikan. Yogyakarta:IRCiSoD.

Umiarso dan Zazin, Nur. 2011. Pesantren di Tengah Arus Mutu Pendidikan Menjawab Problematika Kontemporer Manajemen Mutu Pesantren. Semarang. Ra SAIL Mesia Group.

Undang-Undang Nomor 20 Tahun 2003 Tentang Sistem Pendidikan Nasional 
